\title{
Penerapan Model Pembelajaran Berbasis Masalah untuk Meningkatkan Hasil Belajar
}

\author{
Tria Lutfita Sari ${ }^{*}$, Henny Dewi Koeswanti ${ }^{2}$ \\ 1,2 Program Studi Pendidikan Guru Sekolah Dasar Fakultas Keguruan dan Ilmu Pendidikan Universitas Kristen Satya Wacana
}

\section{A R T I C L E I N F O}

Article history:

Received 19 February 2019

Received in revised form

30 March 2019

Accepted 10April 2019

Available online 20 May 2019

Kata Kunci:

Tema 6 Subtema 3

Pembelajaran 1 dan 2,

Pembelajaran Berbasis

Masalah, dan Hasil Belajar.

Keywords:

Theme 6 Subtema 3

Learning 1 and 2, Problem

Based Learning, and

Learning Outcomes.

\begin{abstract}
A B S T R A K
Penelitian tindakan kelas ini dilakukan untuk meningkatkan hasil belajar Tema 6 Subtema 3 Pembelajaran 1 dan 2 dengan menerapkan model Pembelajaran Berbasis Masalah pada siswa kelas $\mathrm{V}$ yang terdiri dari 16 siswa. Meningkatkan hasil belajar Tema 6 Subtema 3 Pembelajaran 1 dan 2 dengan menerapkan model Pembelajaran Berbasis Masalah. Faktor-faktor yang menyebabkan peningkatan hasil belajar Tema 6 Subtema 3 Pembelajaran 1 dan 2 dengan penerapan model Pembelajaran Berbasis Masalah Siswa Kelas V SD N Kutowinangun 10 Salatiga. Subjek penelitian adalah siswa kelas $\mathrm{V}$ dengan jumlah 16 siswa. Hasil penelitian adalah peningkatan hasil belajar sebelum tindakan dilakukan untuk siklus I dan siklus II. Hasil belajar pada pra siklus dengan persentase $31,25 \%$, kemudian ada peningkatan di siklus I dengan persentase $43,75 \%$. Selanjutnya hasil belajar siklus II meningkat dengan persentase $81,25 \%$, dibuktikan dengan adanya penerapan model Pembelajaran Berbasis Masalah dapat meningkatkan hasil belajar Tematik Siswa Kelas V SD N Kutowinangun 10 Salatiga.
\end{abstract}

\section{A B S T R A C T}

This classroom action research was conducted to improve the learning outcomes of Theme 6 of Theme 3 of Learning 1 and 2 by applying the Problem Based Learning model to class $V$ students consisting of 16 students. Improve learning outcomes Theme 6 Subtema 3 Learning 1 and 2 by applying the Problem Based Learning model. Factors that lead to an increase in learning outcomes Theme 6 of Sub-theme 3 Learning 1 and 2 by applying the Problem-Based Learning Model of Class $V$ Students of SD N Kutowinangun 10 Salatiga. The research subjects were grade V students with 16 students. The results of the study were an increase in learning outcomes before the action was carried out for cycle I and cycle II. Learning outcomes at pre-cycle with a percentage of $31.25 \%$, then there is an increase in the first cycle with a percentage of $43.75 \%$. Furthermore the learning outcomes of the second cycle increased by a percentage of $81.25 \%$, as evidenced by the application of the Problem Based Learning model to improve the Thematic learning outcomes of Grade V Students of SD N Kutowinangun 10 Salatiga. 


\section{Pendahuluan}

Pembelajaran tematik integratif merupakan salah satu model pembelajaran terpadu yang merupakan suatu sistem pembelajaran yang memungkinkan siswa baik secara individual maupun kelompok aktif mengali dan menemukan konsep serta prinsip-prinsip keilmuan secara holistik, bermakna dan otentik (Rusman, 2012: 254). Menurut Trianto (2010: 78) pembelajaran tematik dimaknai sebagai pembelajaran yang dirancang berdasarkan tema-tema tertentu. Setara dengan pendapat Prastowo (2013: 223) pembelajaran tematik terpadu merupakan pendekatan pembelajaran yang mengintegrasikan berbagai kompetensi dari berbagai mata pelajaran ke dalam berbagai tema.

Hal ini dimaksudkan untuk memberikan pemahaman kepada siswa dalam mengenal, memahami berbagai materi menggunakan pendekatan ilmiah, bahwa informasi bisa berasal dari mana saja, kapan saja, tidak bergantung pada informasi searah dari guru. Tidak hanya itu, diharapkan juga agar siswa mampu merumuskan masalah (dengan banyak menanya), bukan hanya menyelesaikan masalah dengan menjawab saja serta diarahkan untuk melatih berpikir analitis (siswa diajarkan bagaimana mengambil keputusan) bukan berpikir mekanistis (rutin dengan hanya mendengarkan dan menghapal saja).

Pembelajaran tematik integratif dengan pendekatan scientific seharusnya guru dapat menciptakan pembelajaran yang memuat ekplorasi, elaborasi dan konfirmasi, serta menekankan pada kondisi siswa yang berperilaku ilmiah dengan bersama-sama diajak mengamati, menanya, menalar, mencoba dan mengomunikasikan (5M), sehingga siswa akan dapat dengan benar menguasai materi yang dipelajari dengan baik. Pembelajaran bisa terjadi di mana saja dan pada level yang berbeda-beda, secara individual, kolektif, ataupun sosial.

Hasil belajar sanggat erat dengan proses kegiatan pembelajaran. Hasil belajar merupakan suatu sasaran atau tujuan dari proses belajar tersebut. Sehingga dapat dikatakan bahwa hasil belajar merupakan perolehan dari proses kegiatan belajar yang diperoleh siswa dengan tujuan pembelajaran yang hendak di capai. Keberhasilan dari suatu proses belajar belajar dapat dilihat melalui hasil belajar yang diperoleh. Hasil belajar merupakan kemampuan yang dimiliki siswa setelah ia menerima pengalaman belajarnya (Sudjana, 2011: 22). Sedangkan menurut Hamalik (2013:33) menyatakan bahwa hasil belajar adalah bila seseorang belajar maka akan terjadi perubahan tingkah laku pada seseorang tersebut. Dari pendapat Oemar Hamalik hasil belajar merupakan perubahan dari hal tidak tahu menjadi tahu, yang tidak mengerti menjadi mengerti yang merupakan hasil dari belajar seseorang.

Didapatkan data berupa hasil pretes siswa yang nilainya masih dibawah Kriteria Ketuntasan Minimal (KKM) yaitu pada muatan IPA. Untuk Kriteria Ketuntasan Minimal (KKM) di SD N Kutowinangun 10 Salatiga yaitu 65. 5 dari 16 siswa sudah mencapai nilai Kriteria Ketuntasan Minimal (KKM) denan presentase $31,25 \%$ dan 11 dari 16 siswa tidak mencapai nilai kriteria ketuntasan minimal (KKM) dengan presentase $68,75 \%$. Tidak tercapainya tujuan pembelajaran tersebut disebabkan oleh beberapa faktor yaitu, pada saat pembelajaran model yang diterapkan kurang bervariasi, oleh sebab itu siswa pada kegiatan pembelajaran cenderung pasif, selain itu saat proses pembelajaran masih terdapat beberapa siswa yang masih berbicara dengan teman sebangkunya. Faktor lainnya yaitu pada sarana dan prasarana untuk mendukung proses pembelajaran seperti halnya LCD dan proyektor, sebenarnya dari pihak sekolah sudah menyediakan tetapi penggunaannya harus bergantian dengan kelas lain.

Salah satu model pembelajaran yang memberikan peluang bagi siswa untuk memiliki pengalaman menemukan suatu konsep dan mengembangkan ketrampilan berpikir kritis adalah model Pembelajaran Berbasis Masalah. Model Pembelajaran Berbasis Masalah atau biasa disingkat dengan PBL merupakan satu bentuk model pembelajaran inovatif yang berpusat pada siswa dan menempatkan siswa pada suatu masalah konkret yan ada disekitar mereka (Koeswanti, 2018: 65). Pada model Pembelajaran Berbasis Masalah, peserta didik dituntut aktif untuk mendapatkan konsep yang dapat diterapkan dengan jalan memecahkan masalah, peserta didik akan mengekplorasi sendiri konsep-konsep yang harus mereka kuasai, dan peserta didik diaktifkan untuk bertanya dalam berargumentasi melakukan diskusi, mengasah ketampilan investigasi, dan menjalani prosedur kerja ilmiah lainnya menurut Permana ( dalam Koeswanti, 2018:74).

Berdasarkan permasalah yang terjadi di SD N Kutowinangun 10 Salatiga, maka diadakan Penelitian Tindakan Kelas (PTK) dengan judul "penerapan model pembelajaran berbasis masalah untuk meningkatkan hasil belajar tema 6 kelas V SD N Kutowinangun 10 Salatiga" suatu penelitian tentu mempunyai permasalahan yang harus diatasi dan dipecahkan. Dalam penelitian ini dapat dirumuskan "Apakah model Pembelajaran Berbasis Masalah dapat meningkatkan hasil belajar IPA pada siswa kelas V SD N Kutowinangun 10 Salatiga? Dan Bagaimana penerapan model Pembelajaran Berbasis Masalah dapat meningkatkan hasil belajar IPA pada siswa kelas V SD N Kutowinangun 10 Salatiga?. Penelitian ini bertujuan meningkatkan hasil belajar IPA melalui Model Pembelajaran Berbasis Masalah siswa kelas V SD 
N Kutowinangun 10 Salatiga dan menerapkan Model Pembelajaran Berbasis Masalah untuk meningkatkan hasil belajar siswa kelas V SD N Kutowinangun 10 Salatiga.

\section{Metode}

Jenis penelitian dari penelitian ini yaitu Penelitian Tindakan Kelas (PTK). Penelitian tindakan kelas yaitu penelitian yang dimaksudkan untuk memperbaiki suatu kegiatan pembelajaran di kelas. Menurut Koeswanti (2018: 191), Penelitian Tindakan Kelas (PTK) termasuk penelitian yang reflektif. Kegiatan penelitian dimulai dari permasalahan yang rill yang dihadapi oleh guru dalam proses pembelajaran. Penelitian tindakan kelas membutuhkan kerjasama antara peneliti, guru, siswa, dan staff sekolah lainnya untuk menciptakan suatu kinerja sekolah yang lebih baik

Adanya model Penelitian Tindakan Kelas (PTK) yang digunakan Stephen Kemmis dan Robin Mc Taggart yang dikutip oleh Pardjini dalam penduan penelitian tindakan kelas (2007), penelitian tindakan kelas ini dilaksanakan dalam beberapa siklus. Setiap siklusnya meliputi beberapa tahapan yaitu perencanaan (planning), tindakan (action), pengamatan (observation) dan refleksi (reflection).

Penelitian ini dilaksanakan pada bulan Februari 2019. Subjek penelitian adalah siswa kelas V SD N Kutowinangun 10 Salatiga dengan jumlah 16 siswa. sistem pembelajaran masih konvensional sehingga anak cenderung bosan dan tidak memperhatikan pembelajaran. Hal ini berdampak pada rendahnya hasil belajar siswa.

Teknik pengumpulan data pada penelitian ini adalah tes, observasi, dan dokumentasi. Tes digunakan untuk mengetahui peningkatan hasil belajar Tema 6 Subtema 3 Pembelajaran 1 dengan muatan Bahasa Indonesia, IPA, dan SBdP siswa kelas V. Tes yang diberikan berupa soal pilihan ganda yang terdiri dari 20 butir soal. Sebelum soal tes diujikan, terlebih dahulu diuji validitas dan reliabilitas terlebih dahulu, pengujian soal validitas dilakukan pada siswa kelas VI SD N Kutowinangun 10 Salatiga, untuk soal uji validitas terdiri dari 62 butir soal yang kemudian hasilnya akan diolah menggunakan SPSS untuk mengetahui soal yang valid untuk diggunakan sebaai bahan evaluasi. Tes evaluasi dilakukan pada akhir kegiatan setiap siklus. Selanjutnya pengumpulan data menggunakan lembar observasi guru dan lembar observasi siswa, lembar ini digunakan untuk mengetahui dan mengamati proses pembelajaran apakah sudah sesuai atau belum degan Rencana Pelaksanaan Pembelajaran (RPP). Teknik dokumentasi yaitu pengumpulan data berupa foto saat proses pembelajaran berlangsung.

\section{Hasil dan Pembahasan}

Berdasarkan pengamatan dan hasil analisa terhadap data yang dieroleh dari pra siklus, siklus I, dan siklus II, maka dapat disimpulkan bahwa dengan menerapkan model Pembelajaran Berbasis Masalah dapat meningkatkan hasil belajar Tema 6 Subtema 3 Pembelajaran 1 dan 2 menunjukkan peningkatan hasil belajar pada siswa kelas V SD N Kutowinangun 10 Salatiga.

Pra Siklus

Pada kondisi awal (pra siklus) rata-rata hasil belajar siswa 52,5 dengan kategori "Rendah". Siswa yang mencapai Kriteria Ketuntasan Minimal (KKM) hanya 5 dari 16 siswa dengan persentase $31,25 \%$. Ada 11 dari 16 siswa dengan persentase 68,75\% belum mencapai Kriteria Ketuntasan Minimal (KKM). Ratarata pra siklus yaitu 52,5. Kriteria Ketuntasan Minimal (KKM) yang ditetapkan oleh sekolah yaitu 65. Oleh karena itu penulis perlu melakukan tindakan dengan menerapkannya model Pembelajaran Berbasis Masalah pada siklus I.

Siklus I

Pada siklus I, penerapan model Pembelajaran Berbasis Masalah hasil belajar siswa meningkat pada siklus pertama. 7 dari 16 siswa sudah mencapai Kriteria Ketuntasan Minimal (KKM) dengan presentase 43,75\% dan 9 dari 16 siswa belum mencapai Kriteria Ketuntasan Minimal (KKM) denan presentase $56,25 \%$. Berdasarkan data yang telah diketahui oleh peneliti telah terjadi peningkatan jumlah siswa yang tuntas dari Kriteria Ketuntasan Minimal (KKM). Dalam siklus pertama masih belum berhasil, oleh karena itu peneliti melakukan tindakan di siklus II.

Siklus II

Pada siklus II, capaian rata-rata siswa adalah 74,8. Ada 13 dari 16 siswa sudah mencapai Kriteria Ketuntasan Minimal (KKM) dengan persentase $81,25 \%$ yang menunjukkan peningkatan dari tindakan siklus pertama. Siswa yang tidak mencapai Kriteria Ketuntasan Minimal (KKM) hanya 3 dari 16 siswa dengan persentase $18,75 \%$. Berdasarkan hasil pengamatan sebagai refleksi dari tindakan pada siklus II ditemukan bahwa guru dapat mempertahankan hasil belajar siswa agar mencapai hasil belajar yang optimal dengan menerapkan berbagai model pembelajaran. 
Berdasarkan hasil pengamatan pada siklus I menunjukkan bahwa aktivitas guru pada siklus I pertemuan pertama mencapai persentase $73,3 \%$ dan di pertemuan kedua dan ketiga menerima persentase $81,7 \%$. Berdasarkan hasil pengamatan yang telah dilakukan masih ada kekurangan yang diperoleh pada siklus I, maka peneliti sebagai sumber belajar melakukan perbaikan pada siklus II, perbaikan-perbaikan tersebut antara lain (1) diharapkan saat kegiatan pendahuluan guru menyampaikan tujuan pembelajaran yang hendak dicapai (2) pengaturan kelas aar suasana belajar kondusif (3) guru kurang dalam memanajemen waktu. Kekurangan tersebut maka dilakukan perbaikan pada siklus II.

Sedangkan hasil dari pengamatan aktivitas guru pada siklus II pertemuan pertama diperoleh $90 \%$, yaitu kedua diperoleh 91,7\%. Dengan demikian, pengamatan aktivitas guru sudah mencapai kriteria indikator sangat baik. Perbandingan aktivitas guru dalam pembelajaran Tematik siklus I dan siklus II ditunjukkan pada tabel berikut.

Tabel 1. Perbandingan Aktivitas Guru Siklus I dan Siklus II

\begin{tabular}{lllccccc}
\hline No & Aktivitas Guru & \multicolumn{2}{c}{ Siklus I } & \multicolumn{2}{c}{ Siklus II } \\
& & Skor & \% & Kriteria & Skor & \% & Kriteria \\
\hline 1 & Pertemuan pertama & 88 & 73,3 & Baik & 108 & 90 & Sangat Baik \\
2 & Pertemuan kedua & 98 & 81,7 & Sangat Baik & 110 & 91,7 & Sangat Baik \\
\hline
\end{tabular}

Berdasarkan hasil pengamatan pada siklus I menunjukkan bahwa aktivitas siswa pada siklus I pertemuan pertama mencapai persentase $75 \%$ dan di pertemuan kedua dan ketiga menerima persentase 81\%. Berdasarkan hasil pengamatan yang telah dilakukan masih ada kekurangan yang diperoleh pada siklus I, maka peneliti sebagai sumber belajar melakukan perbaikan pada siklus II, perbaikan-perbaikan tersebut antara lain (1) siswa kurang memperhatikan guru saat penyampaian materi (2) siswa kurang aktif dalam berpendapat. Kekurangan tersebut maka dilakukan perbaikan pada siklus II.

Sedangkan hasil dari pengamatan aktivitas siswa pada siklus II pertemuan pertama diperoleh 93\%, yaitu kedua diperoleh 96\% menunjukkan peningkatan dari aktivitas siswa dari siklus sebelumnya. Perbandingan aktivitas siswa dalam pembelajaran Tematik siklus I dan siklus II ditunjukkan pada tabel berikut.

Tabel 2. Perbandingan Aktivitas Siswa Siklus I dan Siklus II

\begin{tabular}{|c|c|c|c|c|c|c|c|}
\hline \multirow[t]{2}{*}{ No } & \multirow[t]{2}{*}{ Aktivitas Siswa } & \multicolumn{3}{|c|}{ Siklus I } & \multicolumn{3}{|c|}{ Siklus II } \\
\hline & & Skor & $\%$ & Kriteria & Skor & $\%$ & Kriteria \\
\hline 1 & Pertemuan pertama & 88 & 75 & Baik & 109 & 93 & Sangat Baik \\
\hline 2 & Pertemuan kedua & 94 & 81 & Sangat Baik & 111 & 96 & Sangat Baik \\
\hline
\end{tabular}

Sebelum diterapkannya model Pembelajaran Berbasis Masalah Siswa yang mencapai Kriteria Ketuntasan Minimal (KKM) hanya 5 dari 16 siswa dengan persentase 31,25\% sudah mencapai Kriteria Ketuntasan Minimal (KKM) sedangkan 11 dari 16 siswa dengan persentase 68,75\% belum mencapai Kriteria Ketuntasan Minimal (KKM). Rata-rata pra siklus yaitu 52,5. Setelah diterapkan model Pembelajaran Berbasis Masalah pada Tema 6, hasil belajar mengalami peningkatan. Pada siklus I siswa yang mencapai Kriteria Ketuntasan Minimal (KKM) ada 7 dari 16 siswa dengan persentase 43,7\% dan siswa yang belum mencapai Kriteria Ketuntasan Minimal (KKM) ada 9 dari 16 siswa dengan persentase 56,25\%. Rata-rata hasil belajar pada siklus I yaitu 58,5. Pada siklus II, hasil belajar mengalami peningkatan dari siklus I. Jumlah siswa yang mencapai KKM ada 13 dari 16 siswa dengan persentase 81\% dan siswa yang belum mencapai KKM ada 3 dari 16 siswa dengan persentase 19\%. Rata-rata hasil belajar pada siklus II adalah 74,6. Perbandingan ketuntasan hasil belajar siswa pada prasiklus, siklus I, dan siklus II dapat dilihat pada tabel 3 berikut:

Tabel 3. Perbandingan Ketuntasan Hasil Belajar Siswa Prasiklus, Siklus I, dan Siklus II

\begin{tabular}{|c|c|c|c|c|c|c|c|c|}
\hline \multirow{2}{*}{ No } & \multirow{2}{*}{$\begin{array}{c}\text { Ketuntasan } \\
\text { Belajar } \\
\end{array}$} & \multirow{2}{*}{ Nilai } & \multicolumn{2}{|c|}{ Prasiklus } & \multicolumn{2}{|c|}{ Siklus I } & \multicolumn{2}{|c|}{ Siklus II } \\
\hline & & & Jumlah & $\%$ & Jumlah & $\%$ & Jumlah & $\%$ \\
\hline 1 & Belum Tuntas & $<65$ & 11 & 31,23 & 7 & 43,75 & 13 & 81,25 \\
\hline 2 & Tuntas & $\geq 65$ & 5 & 68,75 & 9 & 56,25 & 3 & 18,75 \\
\hline & Jumlah & & 16 & 100 & 16 & 100 & 16 & 100 \\
\hline
\end{tabular}


Berdasarkan Tabel 3. mengenai perbandingan ketuntasan hasil belajar siswa pada prasiklus, siklus I, dan siklus II, jumlah siswa yang mencapai KKM mengalami peningkatan. Untuk lebih jelas mengenai perbandingan persentase ketuntasan hasil belajar siswa pada prasiklus, siklus I, dan siklus II dapat dilihat pada gambar 1 berikut:

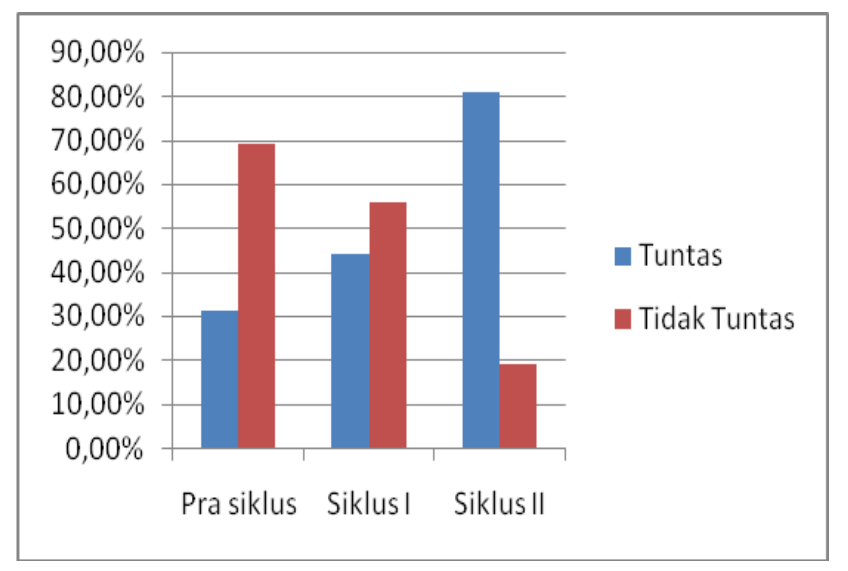

Gambar 1. Ketuntasan Hasil Belajar Tema 6 Prasiklus, Siklus I, dan Siklus II berikut:

Nilai rata-rata hasil belajar siswa prasiklus, siklus I, dan siklus II dapat dilihat pada gambar 2

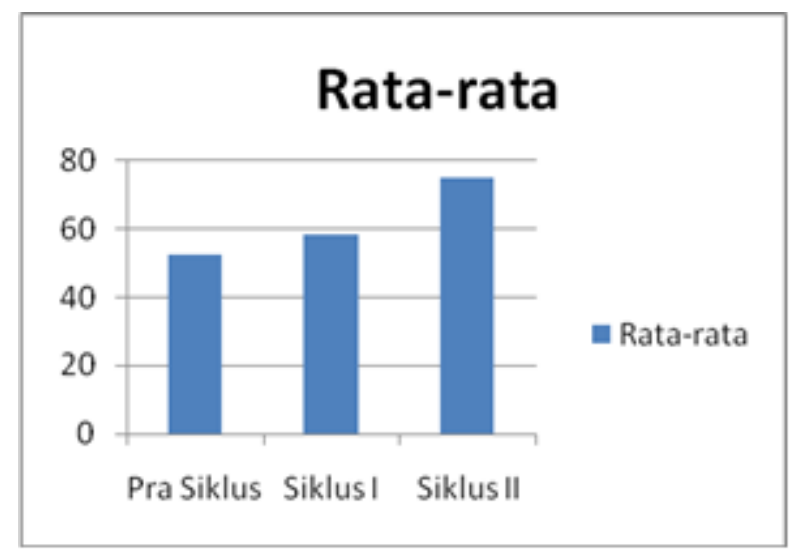

Gambar 2. Rata-rata Hasil Belajar Tema 6 Prasiklus, Siklus I, dan Siklus II

Pada gambar 2 dapat disimpulkan bahwa hasil belajar Tema 6 prasiklus, siklus I dan siklus II meningkat. Pada prasiklus nilai rata-rata yaitu 52,5, pada siklus I rata-rata meningkat menjadi 58,5 , sedangkan pada siklus II rata-rata meningkat menjadi 75.

Berdasarkah hasil observasi yang telah dilakukan di kelas V SD N Kutowinangun 10 Salatiga dan hasil analisis data, diketahui bahwa sebelum tindakan metode pembelajaran menggunakan ceramah. Model pembelajaran yang digunakan kurang bervariatif. Adapun dalam proses pembelajaran siswa pasif. Hal tersebut akan berdampak pada hasil belajar siswa.

Saat penerapan model Pembelajaran Berbasis Masalah pada pembelajaran Tema 6 Subtema 3 Pembelajaran 1 dan 2 diketahui adanya peningkatan dari tahap pra siklus, siklus I, dan siklus II. Siswa menjadi lebih aktif untuk bertanya, berani mengemukakan pendapat, dapat berinteraksi dengan baik selama diskusi dengan kelompok. Aktivitas guru dan aktivitas siswa pada pembelajaran Tema 6 denan penerapan model dapat dikatakan berhasil apabila terjadi peningkatan secara sinifikan.

Pada pra siklus sebelum diterapkannya model Pembelajaran Berbasis Masalah diketahui siswa yang mencapai Kriteria Ketuntasan Minimal (KKM) hanya 5 dari 16 siswa dengan persentase 31,25\%. Sedangkan 11 dari 16 siswa dengan persentase 68,75\% belum mencapai Kriteria Ketuntasan Minimal (KKM) denan rata-rata 52,5. Setalah diterapkannya model Pembelajaran Berbasis Masalah kemudian setelah dilakukan pembelajaran pada siklus I siswa yang mencapai Kriteria Ketuntasan Minimal (KKM) ada 7 dari 16 siswa dengan persentase 43,7\% dan siswa yang belum mencapai Kriteria Ketuntasan Minimal (KKM) ada 9 dari 16 siswa dengan persentase 56,25\%. Rata-rata hasil belajar pada siklus I yaitu 
58,5. Terjadi peningkatan pada siklus II jumlah siswa yang mencapai KKM ameningkat menjadi 13 dari 16 siswa dengan persentase 81\% dan siswa yang belum mencapai KKM hanya 3 dari 16 siswa dengan persentase 19\%. Rata-rata hasil belajar pada siklus II adalah 74,6. Penelitian yang dilakukan pada siklus II sudah mencapai indikator kinerja. Indikator kinerja dari hasil belajar ditetapkan bahwa penerapan model Pembelajaran Berbasi Masalah dikatakan berhasil jika inimal 80\% siswa mencapai Kriteria Ketuntasan Minimal (KKM). hasil belajar siklus II sudah sesuai dengan indikator kinerja yakni 13 siswa mencapai Kriteria Ketuntasan Minimal (KKM) dengan persentase 81,25\%.

Penelitian ini sejalan dengan penelitian yang dilakukan oleh Islam, Harjono, \& Airlanda, (2018: 613-628) dengan judul "Penerapan Model Problem Based Learning Untuk Meningkatkan Berpikir Kritis dan Hasil Belajar IPA Dalam TEMA 8 Kelas 4 SD”, persentase keseluruhan hasil belajar pada pra siklus 27,3\% meningkat pada siklus I 59\% dan meningkat kembali pada siklus II 95,5\% sesuai indikator keberhasilan. Dengan demikian hasil penelitian menunjukkan bahwa penerapan model problem based learning mampu meningkatkan kemampuan berpikir kritis dan hasil belajar.

Penelitian ini juga relevan dengan penelitian yang dilakukan oleh Rahmasari (2016) dengan judul "Penerapan Model Pembelajaran Problem Based Learning Untuk Meningkatkan Hasil Belajar IPA Kelas IV SD Negeri Nglempong Sleman Yogyakarta", hasil penelitian menunjukkan bahwa keterlaksanaan model Problem Based Learning terbukti dapat meningkatkan hasil belajar IPA. Persentase Hasil nilai mata pelajaran IPA pada pra siklus ialah dari 24 siswa sebanyak 10 siswa masih memiliki nilai $\leq 65$, 9 siswa mendapat nilai 65-75 dan baru 5 siswa yang mendapat nilai $>75$. Setelah siklus 1 hasil nilai mata pelajaran IPA meningkat menjadi 23 siswa yang memiliki nilai $\geq 65$ dan hanya satu siswa saja yang memiliki nilai $\leq 65$. Dari 23 siswa yang nilainya memenuhi kriteria ketuntasan minimal, 13 diantaranya sudah memiliki nilai $>75$.

\section{Simpulan Dan Saran}

Berdasarkan hasil penelitian dan pembahasan maka dapat disimpulkan bahwa model Pembelajaran Berbasis Masalah dapat meningkatkan hasil belajar Tema 6 siswa kelas V SD N Kutowinangun 10 Salatiga Semester II Tahun Pelajaran 2018/2019. Hasl ini dapat dilihat dari peningkatan hasil belajar siswa pada pra siklus, siklus I, dan siklus II.

Diharapkan keberadaan penelitian ini dapat menjadi pertimbangan bagi guru dalam memilih model pembelajaran dalam meningkatkan hasil belajar siswa. Guru perlu melakukan upaya untuk mempertahankan hasil belajar siswa agar mencapai hasil belajar yang optimal dengan menerapkan berbagai model pembelajaran. Kepala sekolah perlu memantau dan menumbuhkan dampak kegiatan Penelitian Tindakan Kelas (PTK), seperti bahan untuk menilai kemajuan yang telah dicapai, sehingga apa yang ditemukan dapat diimplementasikan dalam implementasi pembelajaran di sekolah. Peneliti selanjutnya di pengembangan ilmu diharapkan dapat menggunakan model Pembelajaran Berbasis Masalah sebagai salah satu model pembelajaran yang dapat diterapkan dalam mata pelajaran lain.

\section{Daftar Rujukan}

Islam, f. M., harjono, n., \& airlanda, g. S. (2018). Penerapan model problem based learning untuk meningkatkan berpikir kritis dan hasil belajar ipa dalam tema 8 kelas 4 sd. E-jurnal mitra pendidikan, 2(7), 613-628.

Hamalik, oemar. 2013. Proses belajar mengajar. Jakarta: bumi

Koeswanti, Henny Dewi. 2018. Eksperimen Model Kooperatif Learning dalam Pembelajaran Keterampilan Menulis Karya Ilmiah Mahasiswa Ditinjau dari Kemampuan Berpikir Logis. Salatiga: Satya Wacana University Press.

Madya. Suwarsih. 2007. Teori dan Praktik Penelitian Tindakan. Bandung: Alfabeta.

Prastowo, Andi. 2013. Pengembangan Bahan Ajar Tematik. Yogyakarta: Diva PRESS

Rahmasari, r. (2016). Penerapan model pembelajaran problem based learning untuk meningkatkan hasil belajar ipa kelas iv sd. Basic education, 5(36), 3-456.

Rusman. 2012. Model-model Pembelajaran. Depok: Rajagrafindo Persada 
Sudjana, nana. 2011. Penelitian hasil proses belajar mengajar. Bandung: pt remaja rodakarya.

Trianto. (2010). Mengembangkan Model Pembelajaran Tematik. Jakarta: Prestasi Pustaka.

Octa Puspira Dwi. 2018. Penerapan Model Pembelajaran Berbasis Masalah untuk Meningkatkan Hasil Belajar IPA. Jurnal Pendidikan dan Pembelajaran Biologi. 2(1), 86-95.

Tarigan, Justianus. “Penerapan Model Pembelajaran Berbasis Masalah dengan Bantuan Media Vidio Untuk Meningkatkan Keterampilan Menulis Teks Eksplanasi Siswa Kelas XI IIS SMA NEGERI 1 SINGARAJA. "Journal of education action research 2.2 (2018): 123-133.

Agustini, Putu Putri, MG Rini Kristiantari, and DB KT NGR Semara Putra. "PENERAPAN MODEL PEMBELAJARAN BERBASIS MASALAH BERBANTUAN MEDIA AUDIO VISUAL UNTUK MENINGKATKAN HASIL BELAJAR KETERAMPILAN MENYIMAK TEMA SEJARAH PERADABAN INDONESIA PADA SISWA KELAS V SDN 8 SUMERTA". Mimbar PGSD UNDIKSHA. 4.1 (2016).

Primiani, Novi. "Penerapan model pembelajaran berbasis masalah untuk meningkatkan proses dan hasil belajar pada perkuliahan fisiologi hewan". Prosiding Seminas. 1.2 (2012).

PRATIWI, MUSTIKA, AND ISA BELLA. "Penerapan Model Pembelajaran Berdasarkan Masalah Untuk Meningkatkan Hasil Belajar IPA untk siswa SD". Jurnal Penelitian Pendidikan Guru Sekolah Dasar 1.2 (2013): 1-8.

Kharida, L.A.,A. Rusilowati, and K.Pratikyo. Penerapan model pembelajaran berbasisi masalah untuk peningkatan hasil belajar siswa pada pokok bahasan elastisitas bahan. Jurnal Pendidikan Fisika Indonesia. 5.2 (2009) 